\title{
STRATEGI KOMUNIKASI SOCIAL MEDIA BUZZER @infodenpasar PADA INSTAGRAM DALAM MENYEBARKAN INFORMASI DAN MEMBANGUN OPINI MASYARAKAT KOTA DENPASAR
}

Ulio $^{1}$, I Putu Adi Saskara², I Wayan Yudhasatya Dharma³

Universitas Hindu Negeri I Gusti Bagus Sugriwa Denpasar

Abstract

This research is a qualitative research that examines the Social MediaBuzzer@Infodenpasar Communication Strategy on Instagram in disseminating information and building public opinion in Denpasar City. This research is very important because in today's digitalization era, the use of information technology is to facilitate the public in all lines of activity and the flow of information dissemination and exchange is very fast which often causes uproar in cyberspace because of the rampant circulation of hoax or fake news, an account is present. @infodenpasar on Instagram as a social media buzzer with 885 thousand followers / followers to become credible and trusted news and information presenter accounts in spreading news and information about Denpasar City. In this study, the focus will be on analyzing three problems, namely: (1) Why do the people of Denpasar City choose social media buzzer @infodenpasar account on Instagram in looking for news and information about the city of Denpasar?, (2) How is the social media buzzer @infodenpasar communication strategy on Instagram in disseminating information and building public opinion in Denpasar City, (3) What are the implications of social media buzzer @infodenpasar on Instagram in spreading information and building public opinion in Denpasar City?

The research method used is a qualitative research method, to achieve the research objectives, relevant and adequate data are required. Researchers as a key instrument, the technique of determining informants using a purposive sampling model, while the data collection techniques used observation, interviews and library studies.

\footnotetext{
${ }^{1}$ ulio.sm@uhnsugriwa.ac.id

2 putuadisaskara@uhnsugriwa.ac.id

3 yudhadharma@uhnsugriwa.ac.id
} 
The findings of the study include: Reasons for social media users in choosing the @infodenpasar account as a media in searching for news and information about the city of Denpasar, consumer behavior through several stages of the decision making process, namely information search, alternative evaluation, and purchase decisions the communication strategy used by @infodenpasar is by using redundancy techniques, canalizing techniques, informative techniques, and persuasive techniques. Furthermore, the implications for the communication strategy of the Social Media Buzzer @infodenpasar in disseminating information and building public opinion in the city of Denpasar include: Implications for Community Economic Development, Implications for Easing Access to Education, Implications for Forming Ethics and Decency, and Implications for Safety and Smooth Traffic.

Keywords Communication strategy, Social Media Buzzer, Information Dissemination and Opinion Building

\section{PENDAHULUAN}

Pertengahan abad ke 19, muncul revolusi industri tiga yang ditandai dengan dengan perkembangan sistem digital dan teknologi informasi. Saat ini, telah memasuki revolusi industri empat atau yang sering disebut dengan revolusi industri 4.0, dimana pada revolusi industri ini dimulai era digitalisasi. $\mathrm{Hal}$ ini di indikasi dengan gambaran situasi perubahan gaya hidup dan perilaku individu maupun organisasi atau lembaga. Awal mula penyebutan revolusi industri 4.0, dicetuskan oleh seorang Profesor bernama Klaus Schwab yang merupakan ekonom Jerman dan juga pendiri World Economic Forum (WEF) (Prasetyo dan Sutopo, 2018:18).

Era revolusi industri 4.0 memiliki keunggulan jika dibandingkan dengan revolusi industri sebelumnya. Revolusi industry 4.0 sebuah informasi akan diperoleh dengan mudah dan masyarakat diberikan kebebasan sepenuhnya untuk mengutarakan pendapatanya maupun gagasannya. Seiring perkembangan zaman, tentunya perkembangan teknologi yang mengacu pada digital semakin pesat. Di era digitalisasi ini tidak serta merta memberikan dampak yang baik, namun juga bisa memberikan dampak yang buruk. Tantangan demi tantangan pada era digitalisasi pun semakin banyak. Tantang tersebut bisa saja datang dari berbagai bidang, yang perlu dilakukan oleh masyarakat adalah meningkatkan kualitasnya dalam segi kehidupan (Supadiyanto, 2020:182). Munculnya era digital berkaitan dengan pesatnya perkembangan teknologi internet yang membuat batas privasi setiap orang akan perlahan, bahkan data pribadi akan dengan mudah diakses dan dilacak yang menjadi konsekuensi masyarakat di era digitalisasi.

Menurut Setiawan berpendapat bahwa lahirnya situs jejaring sosial atau media social merupakan salah satu indikasi era digitalisasi. Saat era digitalisasi, hampir semua komunikasi dilakukan dengan gadget. Salah satu tren dari era digitalisasi ini, yakni paperless, dimana penggunaan kertas menjadi lebih sedikit, karena rata-rata masyarakat telah menggunakan gadget seperti, laptop dan smartphone yang memiliki kecanggihan untuk menyimpan maupun membuat dokumen. Iswandi (2019:46) dalam bukunya 
mengatakan bahwa era media baru (New Media) telah memberi perubahan dalam sektor kehidupan seperti sosial (Amedie, 2015), adaptasi antarbudaya (Sawyer, 2011), pertumbuhan ekomoni (DellAnno, 2016) dan politik (Richardson, 2017). Perubahan tersebut menandai adanya satu aktivitas baru pada satu generasi yang dikenal dengan masyarakat milenial. Mengacu pada Foot dan Stoffan (2000), generasi milenial adalah kelompok masyarakat yang lahir antara tahun 1980 hingga 1995. Selain generasi milenial juga ada rentang generasi yang lahir antara tahun 1995 hingga 2010 yang disebut generasi Z, dimana kedua generasi ini adalah masyarakat yang tumbuh, hidup dan berkembang pada iklim komunikasi dengan karakteristik media baru tersebut. Suatu iklim yang lebih terbuka, hiper aktif, saling terhubung setara, kaya data, penuh dengan berbagai kecerdasan buatan melalui berbagai manipulasi dan rekayasa.

Kedua generasi ini merupakan pengguna mayoritas yang aktif pada media baru (new media) atau yang dikenal dengan media sosial (social media). Media sosial adalah media yang digunakan untuk berkomunikasi dengan orang lain dibelahan dunia mana pun secara online melalui internet. Media ini tidak mengharuskan setiap orang yang hendak membagikan suatu hal harus memahami kaidah jurnalistik, tanpa perhatian kaidah jurnalistik pun, seseorang user media social dapat membagikan informasi kepada pengguna media social lainnya, beberapa contoh media sosial adalah Facebook, Twitter, Instagram, line, dan lainlain (Supadiyanto, 2020:116).

Masyarakat dengan adanya sosial media sangat terbantu, selain bermanfaat untuk media komunikasi, kegiatan bisnis, juga sebagai aktualisasi diri untuk memperoleh dan menyebarkanluaskan informasi sehingga masyarakat rela meluangkan dan menghabiskan waktu hingga berjam jam dalam mengakses media sosial. Fenomena masyarakat generasi milenial dan generasi $Z$ yang sangat tergantung media sosial khususnya masyarakat di Kota Denpasar penyebaran informasi seputar tentang kota Denpasar. Seperti akun @infodenpasar pada Instagram yang merupakan akun yang mempunyai positioning bagi masyarakat pengguna media sosial sebagai akun Instagram yang pertama di Kota Denpasar yang menyediakan beragam informasi dan berita seputar Kota Denpasar, misalnya info kemacetan, info kuliner, info kecelakaan lalu lintas, info event, info bencana, info seputar upacara dan penutupan jalan. Hadirnya akun tersebut dapat memudahkan masyarakat di Kota Denpasar dalam beraktivitas dengan penyajian informasi dan berita yang akurat dan menghindari berita hoaks atau berita palsu dengan bekerja sama dengan pihak kepolisian setempat. Pada media sosial Instagram akun @infodenpasar sebagai media penyaji informasi yang kredibel dan terpercaya hal ini terbukti dengan jumlah Follower (pengikut) sebanyak 864 ribu akun @infodenpasar tergolong jumlah yang sangat besar dibandingkan dengan akun sejenis penyaji informasi berita di Kota Denpasar.

Berdasarkan paparan pendahuluan diatas melihat fenomena tersebut, maka penulis tertarik untuk melakukan suatu penelitian tentang pemanfataan teknologi informasi yaitu Strategi Komunikasi Social MediaBuzzer@infodenpasar pada Instagram dalam menyebarkan informasi dan membangun opini masyarakat Kota Denpasar. 


\section{METODE PENELITIAN}

Sesuai dengan rancangan penelitian yang didasarkan atas permasalahan yang akan disajikan dalam Strategi Komunikasi Media Social Buzzer @infodenpasar pada Instagram dalam menyebarkn informasi dan membangun opini masyarakat Kota Denpasar, maka penelitian ini mengacu pada penelitian kualitatif yaitu penelitian yang dilakukan dalam kondisi objek yang alami, peneliti sebagai instrumen kunci, data yang dihasilkan bersifat deskriptif dan analisis data dilakukan secara induktif dan penelitian ini lebih menekankan pada makna.

Dalam penelitian ini untuk memberikan gambaran dan uraian tentang objek yang diteliti, maka jenis penelitian adalah sangat penting dalam penyusunan karya ilmiah, bertujuan untuk membatasi suatu kajian yang telah ditentukan sebelumnya. Adapun jenis penelitian yang dilakukan adalah penelitian kualitatif maksudnya tidak menggunakan angka-angka dalam penyajian dan analisisnya, tetapi mengutamakan analisis deskriftif dan induktif yakni, menggambarkan objek penelitian apa adanya dengan teknik generalisasi yang dimulai dari anggapan-anggapan khusus menjadi suatu kesimpulan yang dianggap mewakili beberapa pendapat yang telah dikemukakan.

\section{HASIL DAN PEMBAHASAN}

Berdasarkan hasil penelitian menunjukkan bahwa adanya upaya yang dilakukan dalam menyebarkan informasi dan membangun opini masyarakat kota Denpasar di akun @infodenpasar ada instragam, penulis menemukan beberapa point sebagai berikut:
Alasan Masyarakat Pengguna Sosial Media Dalam Memilih Soscial Media Buzzer @infodenpasar Pada Instagram Dalam Mencari Informasi Seputar Kota Denpasar.

\section{Pencarian Informasi}

Pencarian informasi mulai dilakukan ketika konsumen memandang bahwa kebutuhan tersebut bisa dipenuhi dengan membeli dan mengkonsumsi suatu produk. Pencarian adalah tahap kedua dari proses pengambilan keputusan, hal ini dapat didefinisikan sebagai aktivasi termotivasi dari pengetahuan yang tersimpan di dalam ingatan atau pemerolehan informasi dari lingkungan. Informasi yang dicari meliputi berbagai produk dan merek yang dianggap bisa memecahkan masalahnya atau memenuhi kebutuhannya (Priansa, 2016:89).

Berkaitan dengan alasan masyarakat pengguna sosial media khususnya Instagram dalam memilih akun @infodenpasar sebagai media informasi online dalam memenuhi kebutuhan berita dan informasi seputar kota Denpasar. Hal tersebut merupakan kembali persoalan ke individu masing masing tentunya sangat beragam alasan dan faktor konsumen dalam memilih dan mengambil keputusan. Studi tentang prilaku konsumen pada masyarakat mengenai proses keputusan pembelian yaitu salah satunya pencarian informasi. Berdasarkan wawancara dengan Yunita yang merupakan pengguna sosial media pengikut (follower) akun @infodenpasar pada Instagram menyatakan.

"Ketika saya dilanda rasa bingung akan kebutuhan berita dan informasi seputar kota, maka @infodenpasar pada Instagram adalah salah satu solusinya, baik itu info lalu lintas, kemacetan, penutupan jalan, info kuliner dan info penting lainnya. Saya biasanya mencari informasi dan berita tentang seputar kota Denpasar ketika ingin berpergian misalnya ke 
suatu tempat, saya memilih membuka Instagram @infodenpasar terlebih dahulu untuk melihat berita atau informasi misalnya, dimana telah terjadi kemacetan lalu lintas atau info penutupan jalan," (wawancara Yunita, 12 September 2020).

\section{Evaluasi Alternatif}

Setelah konsumen mendapat berbagai macam informasi, konsumen akan mengevaluasi alternatif yang ada untuk mengatasi permasalahan yang dihadapinya. Evaluasi alternatif merupakan tahap dalam proses pengambilan keputusan pembelian, dimana konsumen menggunakan informasi yang telah peroleh untuk mengevaluasi merek-merek alternatif dalam satu susunan pilihan.

Studi perilaku konsumen selanjutnya yang berkaitan dengan alasan masyarakat pengguna sosial media khususnya pada Instagram dalam memilih @infodenpasar sebagai media online penyaji berita dan informasi dalam menyebarkan informasi seputar kota Denpasar. Beragam alasan dan faktor yang mempengaruhi perilaku konsumen dalam hal ini masyarakat untuk memilih dan mengambil keputusan penggunan barang atau jasa, setelah melakukan pencarian informasi yakni melakukan evaluasi alternatif untuk menyeleksi informasi-informasi yang telah diperoleh untuk tahap pengambilan keputusan pembelian.
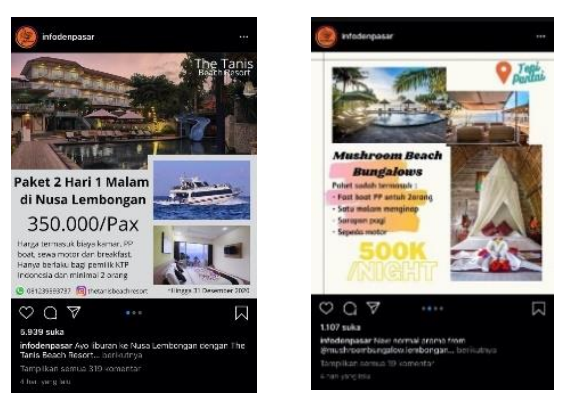

\section{Promosi Paket Liburan Ke Nusa Lembongan di @infodenpasar pada Instagram Sumber: Dokumentasi Peneliti}

Gambar tersebut merupakan salah satu informasi yang dirangkum pada akun @infodenpasar pada Instagram terkait dengan penyajian informasi dan berita yang bervariatif, produk dan jasa pun yang ditawarkan sama sehingga memberikan alternatif pilihan yaitu misalnya informasi promo paket liburan ke Nusa Lembongan. Walaupun tempat untuk promosi sama yaitu akun@infodenpasar pada Instagram akan tetapi agen travel atau pelaku usahanya berbeda dan penawaran pun berbeda mulai dari standar harga, fasilitas yang didapat, tempat hotel dan syarat dan ketentuan promo paket liburan tersebut. Dengan penyajian informasi dan berita yang bervariatif akan menambah alternatif alternatif sebagai bahan evaluasi dalam memudahkan proses pengambilan keputusan bagi konsumen untuk menentukan pilihan yang terbaik.

\section{Keputusan Pembelian}

Apabila tidak ada faktor lain yang mengganggu setelah konsumen menentukan pilihan yang telah ditetapkan, maka pembelian yang aktual adalah hasil akhir dari pencarian dan evaluasi yang telah dilakukan. Keputusan pembelian merupakan pemikiran dimana individu mengevaluasi berbagai 
pilihan dan memutuskan pilihan pada suatu produk dari sekian banyak pilihan. Menurut Kotler \& Amstrong (2014), keputusan pembelian adalah tahap dalam proses pengambilan keputusan pembeli di mana konsumen benar-benar membeli.

Proses pengambilan keputusan pembelian selanjutnya pada studi perilaku konsumen yang berkaitan dengan alasan masyarakat pengguna sosial media dalam memilih akun @infodenpasar sebagai media informasi online dalam mencari berita atau informasi terkait kebutuhannya seputar kota Denpasar. Beberapa faktor yang mendasar mempengaruhi perilaku konsumen dalam kesempatan ini adalah masyarakat untuk memilih dan mengambil sebuah keputusan pembelian terhadap penggunan barang dan jasa, tahap selanjutnya setelah melakukan pencarian informasi, melakukan evaluasi alternatif untuk menyeleksi informasi informasi yang dihimpun, yaitu tahap keputusan pembelian oleh masyarakat pengguna sosial media @infodenpasar. Berdasarkan wawancara dengan Jefry yang merupakan salah seorang pengguna sosial media selaku pengikut (follower) @infodenpasar pada Instagram menyatakan.

"Saya merupakan type orang ketika ingin membeli sesuatu atau menggunakan jasa tertentu, saya sangat teliti dengan memperhatikan hal yang terkecil pun, mulai dari seberapa worth it atau seberapa butuhkah saya barang itu ?, Ketika saya benar butuh sesuatu, saya akan terlebih dahulu mencari informasi dari berbagai sumber akan barang atau jasa yang sama, dan setelah itu selalnjutnya saya meghimpun informasi tersebut kemudia mengevaluasi semua informasi, setelah melakukan evaluasi

tahap akhir yaitu memutuskan produk tersebut yang paling sesuai dengan kebuthan saya." (wawancara Jefry, 13 Oktober 2020)

Berdasarkan keterangan tersebut menyatakan bahwa dalam proses pengambil keputusan pembelian oleh konsumen atau masyarakat, harus melewati beberapa tahap proses sehingga memutuskan produk atau jasa tersebut yang paling sesuai dengan kebutuhan. Bersikap teliti sebagai Langkah awal yang sangat dibutuhkan oleh konsumen atau masyarakat pada saat hendak rencana akan membeli suatu produk atau jasa, memperhitungkan akan seberapa penting barang tersebut dibutuhkan, dan pada saat barang tersebut dibutuhkan, sebaiknya mencari tahu terlebih dahulu informasi dari berbagai sumber tentang barang dan jasa tersebut, kemudian membandingkan beberapa informasi barang yang telah dihimpun untuk dilakukan evaluasi untuk menyeleksi barang dan jasa tersebut, selanjutnya tahap akhir yaitu memutuskan untuk membeli produk dan jasa tersebut berdasarkan hasil akhir evaluasi alternatif

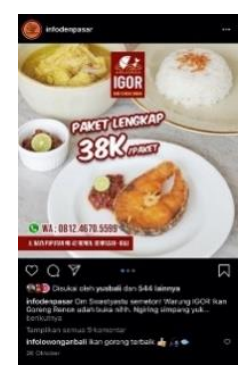

Promosi

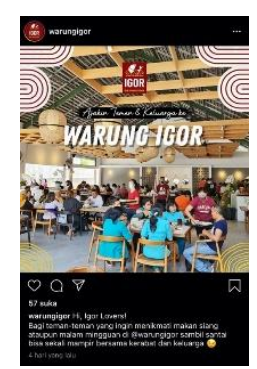

Igor melalui @infodenpasar dan Foto konsumen yang menikmati hidangan di Warung Igor @warungigor setelah mendapatkan informasi tentang Warung Igor dari berbagai media promosi termasuk @infodenpasar Sumber: Dokumentasi Peneliti 
Gambar tersebut merupakan salah satu bentuk informasi yang dirangkum pada akun @infodenpasar pada Instagram terkait dengan proses pengambilan keputusan pembelian terhadap produk dan jasa yang ditawarkan pada akun @infodenpasar. Misalnya promo Warung Igor yang telah melakukan promosi pada akun @infodenpasar. Promosi atas dasar permintaan tersebut dari Warung Igor kepada@@infodenpasar akan mempromosikan paket makanan sesuai yang disediakan oleh Warung Igor. Konsumen atau masyarakat yang mendapat informasi dari berbagai media termasuk informasi dari @infodenpasar. Kemudian bagi konsumen tertarik pasti datang untuk mencicipi makanan ditawarkan warung igor tersebut. Uraian tersebut memberikan sebuah pemahaman bahwa studi perilaku konsumen dalam proses pengambilan keputusan terdiri dari beberapa tahap proses, mulai pengenalan masalah dan pengenalan kebutuhan, pencarian informasi tentang apa yang kita butuhkan, melakukan evaluasi alternatif informasi yang telah dihimpun, terahkir melakukan keputusan pembelian.

\section{Strategi Komunikasi Social Media Buzzer @infodenpasar pada Instagram dalam Menyebarkan Informasi dan Membangun Opini Masyarakat Kota Denpasar \\ Teknik Redundancy (Repetition)}

Berkaitan dengan Strategi komunikasi, salah satu media informasi yakni Social Media Buzzer @infodenpasar dalam menyebarkan informasi dan membangun opini masyarakat kota Denpasar yaitu dengan melakukan teknik penyebaran pesan yang secara berulang. Hal ini tentunya memiliki sebuah alasan yang melatar belakanginya. Berdasarkan wawancara dengan Sudibya,
CEO Social Media Buzzer @infodenpasar pada Instagram menyebutkan.

"Pengulangan informasi dalam sebuah berita bertujuan untuk memberikan informasi secara berkelanjutan. Biasanya hal ini kami lakukan dalam upaya mempromosikan suatu produk dari pelaku usaha baik dalam sekala besar maupun kecil. Teknik redudansi yang kami terapkan dalam memasarkan produk dan jasa dari produsen atau pelaku usaha, untuk waktu penayangan atau pemostingan foto dan video tergantung dari target pangsa pasar. Hal ini berfungsi sebagai sebuah informasi yang sangat berpengaruh pada promosi dan akan memiliki dampak yang positif terhadap pelaku usaha itu sendiri. Dimana masyarakat akan lebih mengenal dan akan terdorong untuk melakukan transaksi pada bidang-bidang usaha yang di promosikan melalui media informasi sesuai dengan kebutuhan mereka (Wawancara Sudibya, 22 Juni 2020).

Berdasarkan wawancara tersebut dapat kita pahami bahwa pengulangan informasi dalam mempromosikan suatu produk dan jasa sangatlah penting. Situasi ini dikarenakan masyarakat tidak selalu dapat melihat informasi dalam satu kesempatan saja, hal ini dipengaruhi karena rutinitas masyarakat global yang padat dan krusial sehingga kadang mereka melewatkan informasi yang penting sekalipun dalam kehidupan mereka. Disinilah pentingnya suatu bentuk informasi yang diulang, selaras dengan pernyataan Sudibyo, pengulangan pesan dan informasi ini sangat penting dilaksanakan mengingat hal ini dapat menimbulkan suatu hubungan yang saling 
menguntungkan antara pelaku usaha dan konsumen. Waktu pemostingan pengulangan pesan atau informasi tersebut ditentukan berdasarkan segmentasi dari pangsa pasar yang telah ditargetkan, misalnya iklan gadget untuk pangsa pasarnya bagi kaum milenial yang memiliki kesibukan rutinitas sehari-hari sebagai orang kantoran, maka waktu pemostigan dilakukan pada saat jam istirahat yaitu pukul 12.00-13.00 dan pengulangan informasi dilakukan secara terus menerus untuk hari selanjutnya pada jam yang sama. Dengan adanya hubungan yang saling menguntungkan antara pelaku usaha dan konsumen secara tidak langsung perputaran roda perekonomian sudah berjalan.

\section{Teknik Canalizing}

Teknik canalizing adalah memahami dan meneliti pengaruh kelompok terhadap individu atau khalayak. Pada mulanya komunikator memberikan pesan kepada khalayak, kemudian secara perlahan diubah pola pikir dan sikapnya ke arah yang komunikator kehendaki. Cara inilah yang disebut sebagai metode canalizing. Maksudnya komunikator menyediakan saluran-saluran tertentu untuk menguasai motif-motif yang ada pada diri khalayak. Pada metode ini proses komunikasinya adalah komunikator terlebih dahulu mengenal khalayak kemudian memberikan ide sesuai dengan kepribadian, sikap dan motif khalayak kemudian dirubah sedikit demi sedikit ke arah tujuan yang komunikator kehendaki (Fajar, 2009: 199-200).

Metode Strategi komunikasi Social Media Buzzer @infodenpasar selanjutnya dalam menyebarkan informasi dan membangun opini masyarakat kota Denpasar yaitu dengan melakukan Teknik canalizing atau menyediakan saluran saluran tertentu pada akun @infodenpasar ini dalam penyebaran pesan dan informasi. Menurut Sudibyo selaku CEO @infodenpasar dalam wawancara menyatakan.

"Melihat kebutuhan dari masyarakat pengguna sosial media khususnya kota Denpasar yang lebih cenderung cari yang praktis, sebagai pengelola yang professional maka tentu kami melakukan metode canalizing ini yaitu dengan menyediakan fitur saluran saluran tertentu pada akun @infodenpasar pada Instagram sesuai jenis informasi apa yang warga net butuhkan supaya memudahkan warga net dalam mengakses dan mendapatkan informasi yang tersedia lebih spesifik pada akun @infodenpasar pada Instagram". (wawancara Sudibya, 22 Juni 2020)

Berdasarkan wawancara diatas dapat kita pahami bahwa penyediaan fitur saluran saluran tertentu pada akun @infodenpasar pada Instagram dalam penyediaan informasi dan pesan yang lebih spesifik agar mudah diakses. Pada kesempatan ini pengguna sosial media yang lebih cenderung untuk hal yang praktis dalam mengakses fitur fitur pada @infodenpasar dalam mencari informasi. Penggunanaan canalizing ini atau fitur saluran saluran tertentu ini pada akun @infodenpasar selain memudahkan pengguna sosial media untuk mengakses juga juga tampak fitur fitur yang tersedia lebih rapi dan tertata lebih profesional pengolahannya. Fitur saluran yang tersedia akun @infodenpasar pada Instagram antara lain, saluran Youtube, Rerahinan, Movies 2020, Liburan 2020, Kulineran, Telp Penting. dengan beragamnya fitur saluran akan menarik minat pengguna sosial media untuk

WIDYA DUTA | VOL. 16, NO. 1 |2021 
mengakses sesuai dengan kebutuhan masingmasing.

\section{Teknik Informatif}

Komunikasi informatif adalah jenis komunikasi yang bertujuan memberikan informasi atau penjelasan. Isi informasi itu sendiri bisa bersifat pemaparan pandangan. Ada tiga hal yang harus diperhatikan agar komunikasi informatif ini dapat berhasil yaitu: menarik perhatian, mengusahakan agar komunikan bersedia menerima isi pesan, komunikan bersedia menyimpan isi pesan. Fungsi komunikasi informatif adalah Organisasi dapat dipandang sebagai suatu sistem pemrosesan informasi. Maksudnya, seluruh anggota dalam suatu organisasi berharap dapat memperoleh informasi yang lebih banyak, lebih baik dan tepat waktu. Informasi yang didapat memungkinkan setiap anggota organisasi dapat melaksanakan pekerjaannya secara lebih pasti. Orang-orang dalam tataran manajemen membutuhkan informasi untuk membuat suatu kebijakan organisasi ataupun guna mengatasi konflik yang terjadi di dalam organisasi (Suryadi, 2018: 118).

Strategi komunikasi akun @infodenpasar pada Instagram, selain bentuk pelaksanaan juga terdapat teknik menurut bentuk isi pesannya dalam menyebarkan pesan dan informasi kepada masyarakat yaitu melakukan dengan Teknik informatif. Hal tersebut didasari berdasarkan wawancara dengan Sudibya selaku CEO @infodenpasar pada Instagram menyampaikan.

"Semua data dan informasi, kami sajikan dari akun @infodenpasar untuk pengguna media sosial pengikut @infodenpasar pada Instagram merupakan data atau informasi adalah benar apa adanya, apa sesungguhnya, berdasarkan fakta fakta yang terjadi dilapangan dan pendapat pendapat yang benar. Hal ini sudah menjadi komitmen kami sebagai media digital yang independent yang menyajikan beragam berita yang faktual dan terpercaya karena menyangkut kapabel dan kredibiltas media kami." Dan kami telah melakukan bekerjasama dengan pihak Kepolisian Divisi Humas Polres seluruh provinsi Bali untuk menghindari berita yang kurang akurat atau berita palsu/hoaks (wawancara Sudibya, 01 Juli 2020)

Berdasarkan wawancara diatas dapat kita pahami bahwa informasi dan berita yang disajikan @infodenpasar pada Instagram adalah informasi dan berita yang berdasarkan fakta yang terjadi dilapangan, hal ini pun telah dilakukan beberapa strategi dalam mengola data akan dijadikan berita untuk menghindari berita palsu (berita hoaks) yaitu dengan melakukan kerja sama dengan pihak Divisi Humas Kepolisian diseluruh Polres diseluruh provinsi Bali khususnya Polresta Denpasar, kerja sama yang dilakukan dengan pihak kepolisian pun mendapatkan feedback atau umpan balik bagi pihak kepolisian yaitu dengan system penyebaran informasi yang cepat memudahkan pihak kepolisian dalam aksi cepat tanggap dalam mengatasi permasalahan yang terjadi dimasyarakat khususnya kota Denpasar. Hal yang serupa juga diungkapkan oleh Irpan yang berupakan salah seorang pengguna sosial media sebagai pengikut (follower) akun @infodenpasar pada Instagram dalam sebuah wawancara.

"Saya selaku pengguna sosial media khususnya Instagram dan merupakan pengikut (follower) @infodenpasar selama 4 tahun 
terahkir sejak tahun 2016 sampai sekarang, saya selalu mendapatkan informasi dan berita yang saya butuhkan tentang seputar kota Denpasar dari akun @infodenpasar misalnya info kemacetan, info lalu lintas dan beragam info lainnya, dan sampai saat ini saya belum pernah menemukan berita atau informasi yang diralat karena ada kesalahan atau berita dan informasi yang bersifat berita palsu atau hoaks, media penyedia berita seputar kota Denpasar sangat bermanfaat bagi saya maupun dengan masyarakat lainnya tentunya, maka dari itu akun @infodenpasar pada Instagram selalu menjadi acuan atau pedoman dalam mencari informasi atau berita seputar kota Denpasar." (wawancara Irpan, 28 Oktober 2020)

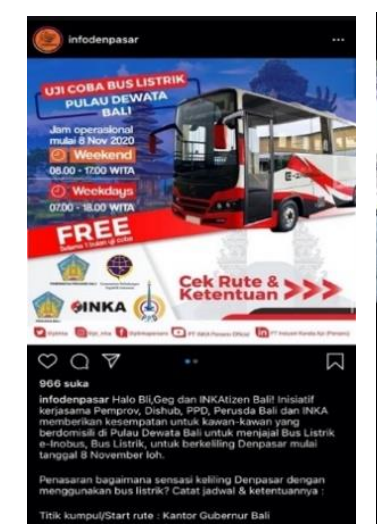

(Strategi Komunikasi

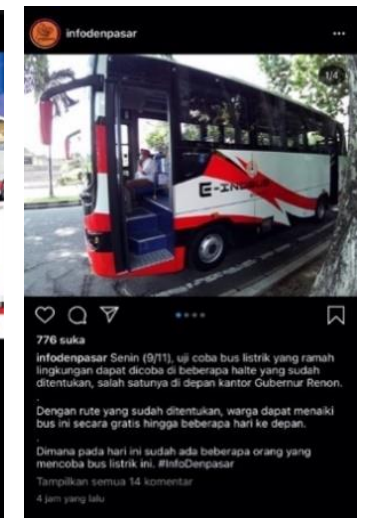

dengan Teknik Informatif) Uji Coba Bus Listik ramah lingkungan @infodenpasar

\section{Sumber: Dokumentasi Peneliti}

Gambar diatas merupakan salah satu informasi yang dirangkum oleh akun @infodenpasar pada Instagram yang terkait dengan kebijakan pemerintah Provinsi Bali tentang penggunaan bus listrik sebagai kendaraan umum dengan mengusung teknologi tinggi kendaraan masa depan yang ramah lingkungan untuk masyarakat Bali. Gambar tersebut berisikan Informasi tentang hari pertama uji coba Bus Listrik pulau dewata Bali yang mendapat antusiasme warga sangat besar untuk mencoba menaiki Bus Listrik tersebut, pada masa uji coba ternyata bus listrik gratis selama sebulan untuk warga Bali, dengan peta rute uji coba Bus Listrik E-Inobus, dan Agenda ini merupakan hasil Kerjasama dari Pemerintah provinsi Bali, Dinas Perhubungan Provinsi Bali, PPD, Perusda Bali dan PT. INKA Persero. Di masa pandemi Covid-19 operasional Bus Listrik tetap menerapkan protokol Kesehatan dari pemerintah, antara lain: bagi penumpang tetap antri tertib dengan menjaga jarak, wajib menggunakan masker selama di Bus, dan dilakukan pemeriksaan suhu tubuh sebelum menaiki bus.

Berdasarkan uraian tersebut diatas memberikan sebuah pemahaman bahwa dalam penyebaran salah satu informasi dan berita dari akun @infodenpasar untuk pengguna sosial media khususnya Instagram, komunikasi pesan yang disampaikan jelas, terarah dan mudah dipahami oleh masyarakat awam dan masyarakat pada umumnya akan membutuhkan informasi tersebut terkait operasional Bus Listrik di wilayah kota Denpasar untuk kelancaran kegiatan dan aktivitas masing-masing. Kemudian untuk strategi pemilihan waktu pemostingan dan penayangan terkait operasional Bus Listrik yang ada di Kota Denpasar biasanya bersifat random atau jam pemostingan tidak ditentukan secara pasti karena informasi dan pesan tersebut disampaikan hanya bersifat pemberitahuan umum yang biasanya berupa berita up-date atau berita terbaru. Dari uraian tersebut maka dapat disimpulkan bahwa strategi 
komunikasi akun @infodenpasar pada Instagram dalam menyebarkan informasi dan membangun opini masyarakat mennggunakan metode informatif atau menggunakan suatu bentuk isi pesan yang bertujuan untuk mempengaruhi khalayak dengan menyampaikan sesuatu apa adanya dan berdasarkan fakta-fakta dan data data yang benar yang terjadi di lapangandan strategi pemilihan waktu pemostingan atau penayangan tetap memperhatikan jenis informasi atau pesan yang akan disebarkan berdasarkan pangsa pasar yang telah ditargetkan.

\section{Teknik Persuasif}

Selanjutnya selain teknik informatif, strategi komunikasi@infodenpasar pada Instagram, berdasarkan teknik bentuk isi pesannya dalam menyebarkan pesan dan informasi kepada masyarakat yaitu dengan melakukan teknik persuasif. Hal tersebut juga diungkapkan berdasarkan wawancara dengan Sudibya selaku CEO @infodenpasar pada Instagram menyampaikan.

"Kami selalu menyajikan dan menawarkan beragam informasi dan berita kepada masyarakat pengguna sosial media khususnya Instagram, tentunya sesuai dengan kebutuhan masyarakat, selain membantu mempromosikan usaha kecil dan menengah seperti kuliner pinggir jalan yang tidak kalah enak dengan harga terjangkau, warung kuliner yang menawarkan makanan yang unik, kenyamanan akan kebersihan dan fasilitas warung makan tersebut, dan atau toko yang melakukan potongan harga (diskon). Cara promosinya pun dilakukan secara professional sekreatif mungkin dan tetap memperhatikan jadwal pemostingan produk dan jasa yang akan dipromosikan sesuai dengan target pasar misalnya bidang kuliner dalam pengambilan foto dan video makanan yang dapat menggugah selera makan untuk mencicipinya." (wawancara Sudibya, 01 Juli 2020)

Berdasarkan wawancara tersebut dapat diketahui bahwa berita atau informasi yang disajikan oleh @infodenpasar pada Instagram adalah berita atau informasi yang dikemas se-kreatif mungkin agar menjaring minat para pengguna sosial media khususnya pengikut (follower) akun @infodenpasar pada Instagram dengan menawarkan berbagai keunggulan dan kelebihan serta membangkitkan daya beli masyarakat akan produk dan jasa yang ditawarkan. Tim professional @infodenpasar dengan ide kreatif dan inovatif dengan dukungan sarana dan prasarana yang memadai akan selalu membuat promosi atau iklan produk dan jasa akan banyak diminati dan digemari namun tetap memperhatikan strategi pemilihan waktu pemostingan dan penanyangan foto atau video produk jasa han hendak dipromosikan, khususnya pangsa pasar masyarakat milenial pemilihan waktu biasanya pada jam istirahat atau jam santai pada pukul 12.00-13.30 siang dan pukul 18.00-22.00 malam, hal ini dilatarbelakangi perilaku konsumen masyarakat milenial apabila jam santai atau jam istirahat akan cenderung memperhatikan iklan tentang keunggulan dan kelebihan produk dan jasa teersebut, alur cerita atau pengalaman (history) produk dan jasa tersebut, pengemasan (packingin). Hal yang sama juga diungkapkan oleh Ilfah yang merupakan salah satu pengguna sosial media yang menjadi 
pengikut (follower) akun @infodenpasar pada Instagram dalam sebuah wawancara.

"Pada jam-jam santai, terkadang saya secara tidak sengaja membuka Instagram dan melihat di akun @infodenpasar, ada promo diskon tentang kuliner atau warung makan yang menyajikan makanan yang unik dan berbeda dari biasanya, dengan tampilan foto atau video makanan tersebut yang kelihatan sangat enak dan lezat serta penawaran harga yang terjangkau, maka saya tidak menunggu waktu yang lama untuk segera mencicipinya. Produk dan jasa pun yang disajikan oleh @infodenpasar, menurut saya selalu menarik karena desain dan tampilan yang unik khususnya kuliner, bukan tidak berasalan bagi saya karena saya sudah punya pengalaman beberapa kali, berawal hanya melihat iklan di Instagram terus langsung mencoba makanan tersebut." (wawancara Ilfah, 24 Oktober 2020)

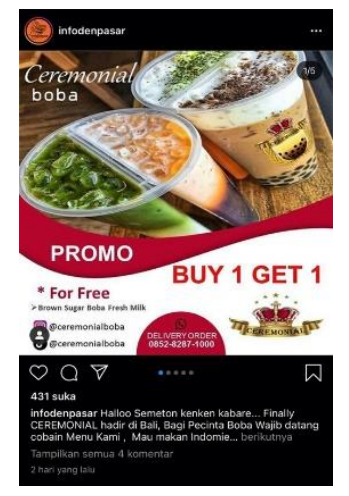

(Strategi Komunikasi dengan Teknik Persuasif) Stimulus Berupa Promo Diskon Kuliner, dan Promo Paket Liburan @infodenpasar

Sumber: Dokumentasi Peneliti
Gambar tersebut merupakan salah satu bentuk informasi yang dirangkum dari akun@infodenpasar pada Instagram yang terkait dengan penyajian berita atau informasi berupa stimulus dengan memberikan promo diskon kuliner misalnya pada Warung Igor dengan paket lengkapnya dan promo pembelian 1 dapat 1 pada Ceremonial Boba, dan waktu pemostingan foto dan video promo diskon kuliner biasanya saat jam istirahat kantor yaitu pada pukul 12.00-13.30 siang, selain untuk kuliner beragam informasi tentang liburan dengan stimulus berupa promo seperti paket liburan ke Nusa Lembongan yang berlaku pada bulan November, dan waktu pemostingan foto dan video promo diskon paket liburan biasanya saat jam pulang kantor yaitu pada pukul 16.00-18.00 sore. Gambar tersebut berisikan informasi tentang warung atau toko dan travel memasarkan produk dan jasa tersebut antara lain mengenai deskripsi harga, produk dan jasa yang ditawarkan dan kontak person untuk informasi lebih lanjut mengenai produk dan jasa tersebut serta info tentang pemesanan. Selain stimulus berupa diskon atau potongan harga, desain dan tampilan foto dan video sangat berpengaruh terhadap keputusan konsumen dalam memilih produk dan jasa tersebut maka dari itu desain dan tampilan akan dibuat semaksimal mungkin agar dapat menarik minat daya beli masyarakat pengguna sosial media khususnya pengikut @infodenpasar pada Instagram.

Berdasarkan dari paparan tersebut dapat diuraikan dengan memberikan suatu pemahaman bahwa akun @infodenpasar pada Instagram dalam menyajikan berita atau informasi dengan mempelajari prilaku konsumen pengguna sosial media khususnya Instagram terhadap segala bentuk kebutuhan 
mereka, salah satu strategi yang dilakukan yaitu dengan memberikan stimulus berupa promo atau dengan potongan harga dari produk dan jasa yang ditawarkan dan memberikan sebuah penyajian berita dan informasi dengan desain dan tampilan yang dikemas se-menarik mungkin agar menumbuhkan daya minat beli dari konsumen untuk produk dan jasa yang ditawarkan tersebut. Dari uraian diatas maka dapat disimpulkan bahwa strategi komunikasi@infodenpasar pada Instagram dalam menyebarkan informasi dan membangun opini masyarakat dengan menggunakan teknik persuasif atau mempengaruhi dengan jalan membujuk dalam hal ini khalayak diberikan stimulus stimulus untuk digugah baik pikiran maupun terutama perasaannya.

\section{Implikasi Social Media Buzzer @Infodenpasar Pada Instagram Dalam Menyebarkan Informasi Dan Membangun Opini Masyarakat Kota Denpasar}

Suatu tindakan atau fenomena akan menimbulkan reaksi tertentu terhadap lingkungan terlebih terhadap lingkungan sosial dalam masyarakat. Hal inilah yang disebut sebagai implikasi dalam penelitian ini. Implikasi berarti keterlibatan atau keadaan terlibat (Tim, 2014: 529). Seperti halnya akun @Infodenpasar pada Instagram sebagai suatu pengantar informasi tentu memiliki dampak terhadap masyarakat yang menjadi sasarannya. Adapun implikasi Social Media Buzzer akun @Infodenpasar terhadap masyarakat Bali dan Denpasar secara mengkhusus adalah sebagai berikut.

\section{Implikasi Terhadap Pengembangan Perekonomian Masyarakat}

Salah satu media komunikasi yang sangat membantu dalam perkembangan perekonomian masyarakat di Bali dan Denpasar secara khusus adalah akun @Infodenpasar pada Instagram. Akun @Infodenpasar pada Instagram merupakan media yang sangat diminati oleh masyarakat Bali secara umum dan Denpasar secara mengkhusus. Media sosial Buzzer @Infodenpasar bergerak di bidang jejaring sosial yang desut dengan Instagram. Instagram merupakan tren masyarakat milenial saat ini terlebih generasi muda yang sebagaian besar menggunakan media sosial ini. Minat masyarakat yang sangat besar dengan media sosial Instagram merupakn strategi yang sangat tepat bagi media sosial Buzzer @Infodenpasar untuk berbagi informasi tentang berbagai hal yang ada di Bali secara umum dan mengkhusus di kota Denpasar. Berdasarkan wawancara dengan Ibu Ayu, seorang pedagang di kota Denpasar menyebutkan.

“Akun @Infodenpasar sangat membantu kami dalam promosi. Mereka datang denga sukarela ke tempat kami memfoto berbagai menu yang kami sajikan dan yang menjadi ciri khas dari warung kami. Kemudian menyebarkanya dalam bentuk berita di media sosial Instagram sehingga banyak dari masyarakat yang tau dan datang ke warung kami untuk menikmati berbagai masakan yang kami sajikan." (Wawancara Ibu Ayu, 29 Juli 2020)

Berdasarkan hasil wawancara tersebut dapat dipahami bahwa media sosial Buzzer @Infodenpasar pada Instagram berperan 
sangat besar dalam memajukan dan mengembangkan perekonomian khususnya bidang usaha mikro yang ditekuni oleh masyarakat. Terlebih proses promosi yang dilakukan bersifat Cuma-Cuma, sehingga masyarakat dari kalangan pengusaha mikro sangat merasa terbantu dengan adanya media sosial Buzzer @Infodenpasar pada Instagram dalam menjajakan dagangan mereka ke semua kalangan masyarakat khususnya yang menggunakan media sosial Instagram untuk mengakses berbagai informasi terkait produk yang di jajakan.

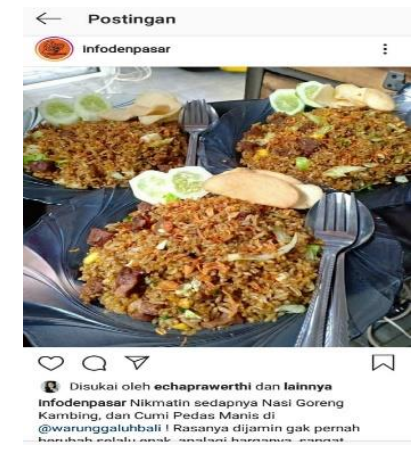

Informasi Seputar Kuliner

Sumber: Dokumentasi Peneliti 2020

Berdasarkan gambar tersebut dapat diketahui bahwa akun @Infodenpasar pada Instagram mengemas suatu berita dengan sangat baik dan menarik. akun @Infodenpasar pada Instagram juga tidak tebang pilih dalam mengelola informasi, bahakan informasi seputar usaha-usaha mikro cendrung dijadikan pilihan informasi yang di posting oleh akun @Infodenpasar pada Instagram. Hal ini bertujuan untuk memberikan informasi yang sederhana dan bermanfaat baik bagi masyarakat luas maupun bagi mereka para masyarakat pengusaha mikro agar terjadi sebuah interaksi yang saling menguntungkan.
Implikasi Mempermudah Akses Pendidikan

Akun@Infodenpasar khusunya yang dapat diakses melalui situs jejaring sosial yang disebut Instagram menyajikan berbagai konten sebagai sebuah program informasi yang ditujukan kepada masyarakat khususnya di Bali. Salah satu konten yang positif yang disajikan oleh akun @Infodenpasar adalah terkait dengan pendidikan yang tentunya bertujuan untuk memberikan edukasi kepada masyarakat. Berdasarkan wawancara dengan Nita, seorang pelajar muda di kota Denpasar menyebutkan.

“@Infodenpasar pada Instagram memberi kami berbagai informasi yang akurat dan terpercaya salah satunya dalam bidang pendidikan. Media sosial Buzzer @Infodenpasar pada Instagram merekomendasikan berbagai tempat pendidikan dan informasi seputar pendidikan yang tentunya sangat bermanfaat bagi kami generasi muda yang sangat membutuhkan hal tersebut." (Wawancara Nita, 25 Oktober 2020).

Berdasarkan hasil wawancara diatas dapat dipahami bahwa konten seputar pendidikan yang disajikan pada akun @Infodenpasar pada Instagram sangat membantu generasi muda Bali dan khususnya di kota Denpasar untuk mengakses berbagai informasi terkait dengan dunia pendidikan. Konten-konten seputar dunia pendidikan tersebut tentunya sangat positif dalam menunjang intelektual masyarakat secara umum dan khususnya generasi muda yang haus dengan pendidikan. Seperti yang kita ketahui pendidikan merupakan komponen yang sangat penting dalam kehidupan manusi. Pendidikan memiliki fungsi yang sangat besar dalam 
mengentaskan berbagai permasalahan kehidupan manusia. Serta pendidikan juga merupakan upaya untuk meningkatkan kualitas hidup manusia yang pada intinya bertujuan untuk memanusiakan manusia, mendewasakan, dan mengubah perilaku menjadi lebih baik.
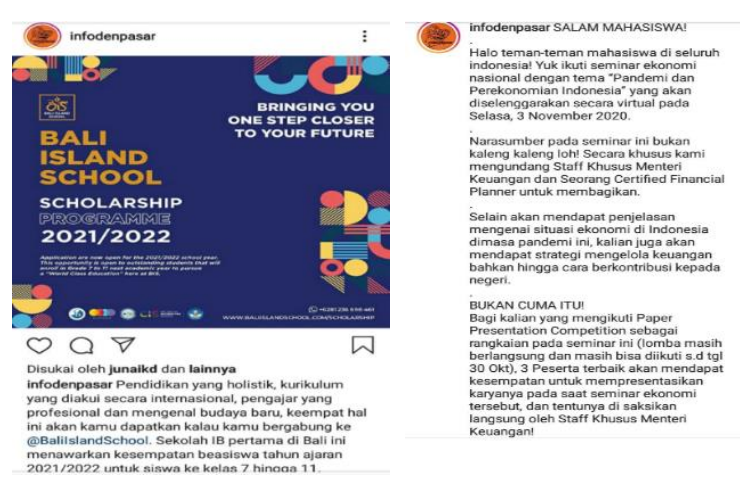

\section{Infodenpasar dalam Memberikan Informasi Pendidikan}

\section{Sumber: Dokumentasi Peneliti 2020}

Berdasarkan gambar tersebut dapat diketahui bahwa media sosial Buzzer @Infodenpasar pada Instagram memberikan suatu informasi terkait dengan pendidikan. Dalam pemberian informasi, media sosial Buzzer @Infodenpasar pada Instagram selalu memberikan ulasan sebagai sebuah pandangan yang tentunya dilator blakangi dari informasi yang falid yang didapatkan melalui perburuan informasi di lapangan. Hasil analisis informasi tersebutlah yang kemudian di unggah ke publik melalui media komunikasi Instagram sebagai sebuah berita harian yang nantinya dapat dibaca dan memberikan informasi kepada masyarakat luas. Informasi tentang pendidikan diaharapkan mampu membantu masyarakat dalam menambah wawasan serta sejalan dengan program pemerintah yakni mengentaskan kebodohan dengan melakukan proses pendidikan yang intens dari berbagai sumber baik buku, media komunikasi, dan media informasi.

\section{Implikasi Membentuk Etika Dan Kesusilaan}

Dalam kaitanya dengan etika dan tata susila, media komunikasi memiliki peranan yang sangat penting untuk menghantarkan berita yang memiliki implikasi etika dan kesusilaan. Media informasi sebagai suatu kebutuhan yang sangat penting ditengahtengah kehidupan masyarakat modern masa kini akan memberikan sebuah cara pandang yang yang menentukan sikap seseorang pada satu hal dan permasalahan. Berita yang disajikan di media komunikasi seolah sebagai sebuah stimulus yang nantinya akan menimbulkan respon dari masyarakat untuk menentukan sikap dalam kehidupan mereka. Salah satu media informasi di Bali yang memiliki peranan dalam membentuk etika dan kesusilaan di tengah-tengah masyarakat adalah akun @Infodenpasar pada Instagram. Media informasi @Infodenpasar pada Instagram merupakan salah satu media informasi yang ternama di Bali dalam usaha memberikan informasi yang akurat dan tentunya sangat menarik, serta dapat memberikan efek dalam kehidupan masyarakat. Berdasarkan wawancara dengan Muniksu, salah satu warga kota Denpasar menyebutkan.

“Akun @Infodenpasar pada
Instagram dalam memberikan
informasi sangatlah akurat. Media ini
menyajikan berita-berita yang
sederhana namun penuh makna dalam
kehidupan masyarakat. Media sosial
Buzzer @Infodenpasar pada Instagram
memberikan dorongan kepada
masyarakat untuk melakukan berbagai
hal positif dalam kehidupan."
(Wawancara Muniksu, 18 Juli 2020)


Berdasarkan wawancara tersebut dapat diketahui bahwa akun @Infodenpasar pada Instagram merupakan media informasi yang akurat dan dapat dipercaya oleh masyarakat khususnya di kota Denpasar. Melalui informasi-informasi yang sederhana namun sangat berarti dalam kehidupan masyarakat, membuat infodenpasar menjadi salah satu media informasi yang sangat diminati oleh banyak kalangan masyarakat di Bali. Berbagai informasi yang dimuat dalam berita yang disajikan di Instagram memberikan dampak yang positif terhadap lingkungan dan masyarakat yang menyimaknya.

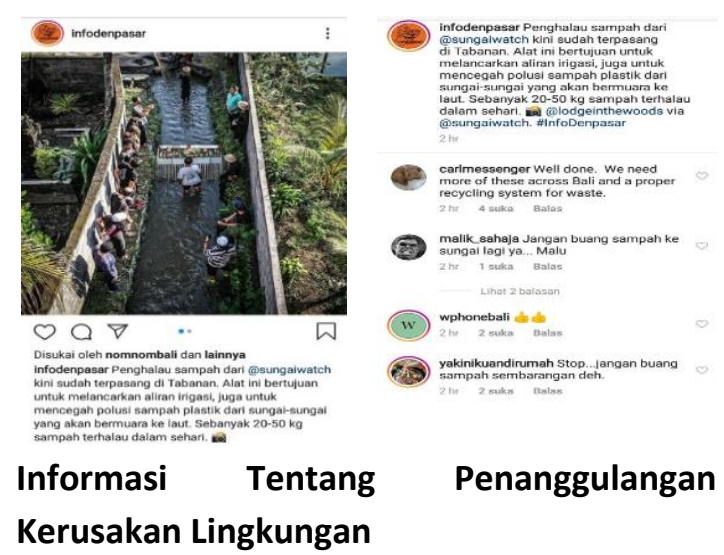

Sumber: Dokumentasi Peneliti 2020

Berdasarkan gambar tersebut dapat kita pahami bahwa akun @Infodenpasar pada Instagram memberikan suatu informasi yang bernilai positif terhadap kehidupan sosial masyarakat. Dengan adanya informasi semacam itu setidaknya masyarakat yang mengetahui informasi ini melalui akun @Infodenpasar pada Instagram akan memiliki rasa enggan untuk membuang sampah sembarangan karena akan memicu kerusakan lingkungan. Informasi yang diberikan oleh akun @Infodenpasar pada Instagram setidaknya dapat membangun kepribadian masyarakat untuk melakukan sesuatu yang lebih baik dan lebih mengandung unsur etika dan kesusilaan. Tidak hanya itu saja, dapat kita ketahui respon masyarakat ketika menanggapi berita yang disajikan oleh akun @Infodenpasar pada Instagram. Masyarakat menanggapinya dengan penuh kesadaran, bahwa dengan mereka buang sampah sembarangan ataupun ke sungai maka hal tersebut akan memicu kerusakan lingkungan. Sehingga beberapa masyarakat dalam komentar menyatakan ketegasannya dan menghimbau kawan-kawannya yang lain untuk tidak lagi membuang sampah di sungai agar lingkungan tetap terjaga dengan baik. Nampaknya aspek etika dan kesusilaan sudah tercermin dalam tanggapan masyarakat tersebut sehingga memunculkan suatu perubahan pada kebiasaan masyarakat yang kurang baik dengan tidak lagi membuang sampah sembarangan. Berita yang di posting oleh akun@Infodenpasar pada Instagram memberikan motifasi kepada masyarakat untuk selalu mentaati nilai etika dan kesusilaan.

\section{Implikasi Keamanan dan Kelancaran Berlalulintas}

Akun@Infodenpasar pada Instagram memberikan berbagai gambaran tentang situasi lalulintas khususnya di kota Denpasar. Informasi yang disajikan akun @Infodenpasar pada Instagram terkait dengan situasi lalulintas di kota Denpasar manjadi sangat penting, mengingat kota Denpasar merupakan jantung kotanya Bali. Sehinga kota Denpasar merupakan tempat yang sangat remain dan sudah dapat dipastikan memiliki intensitas lalulintas yang padat. Berdasarkan wawancara dengan Pak Made, seorang pengendara kendaraan bermotor menyebutkan.

WIDYA DUTA | VOL. 16, NO. 1 |2021 
Media sosial Buzzer

@Infodenpasar pada Instagram sangat membantu kami dalam memilih alternatif tujuan yang aman dari kemacetan. Kami bisa memantau ruasruas jalan di sekitaran kota Denpasar melalui media sosial Buzzer @Infodenpasar pada Instagram setiap hari. Hal ini penting sekali bagi kami yang berpacu dengan waktu untuk menentukan arah mana yang terbaik dan tercepat (Wawancara Pak Made, 12 September)

Berdasarkan hasil wawancara tersebut dapat diketahui bahwa akun @Infodenpasar pada Instagram merupakan media komunikasi yang sangat dibutuhkan oleh masyarakat dalam hal ini yang berkaitan dengan pemberi informasi seputar lalulintas yang aman agar terhindar dari kemacetan di kota Denpasar. Hal ini dikarenakan akun @Infodenpasar pada Instagram menyajikan berbagai informasi di tentang lalulintas selama 24 jam setiap harinya. Jadi bilamana ada masalah lalulintas yang terjadi semua akan bisa kita dapatkan informasinya dengan cepat melalui akun @Infodenpasar pada Instagram.
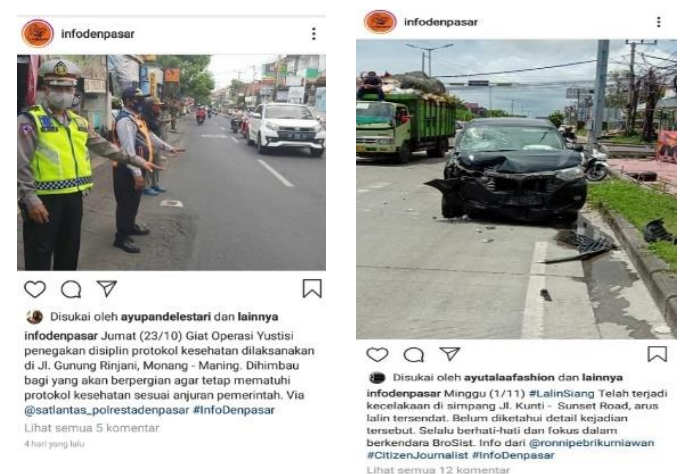

Berdasarkan gambar tersebut dapat dipahami bahwa akun @Infodenpasar pada Instagram memberikan suatu informasi kepada masyarakat tentang diadakannya razia kepatuhan terkait dengan protocol kesehatan maupun informasi tentang kecelakaan lalulintas. Sehingga berdasarkan informasi tersebut masyarakat dihimbau untuk melengkapi diri dengan masker dan handsanitaser serta segala bentuk syaratsyarat yang layak dalam melakukan perjalanan berlalulintas di masa pandemi Covid-19. Dengan adanya akun @Infodenpasar pada Instagram sedikit tidaknya dapat memberikan dorongan terhadap masyarakat untuk lebih disiplin dalam menggunakan serta menerapkan protocol kesehatan dan juga menghimbau untuk mencari jalur lain ketika harus melewati jalan tersebut untuk menghindari kemacetan. Himbauan untuk selalu berhatihati dalam perjalanan berlalu lintas juga selalu disematkan agar masyarakat semakin waspada di jalan raya untuk menghindari kecelakaan dan hal-hal lain yang tidak diinginkan

Berdasarkan uraian tersebut diatas tentunya dapat kita ambil sebuah kesimpulan bahwa akun @Infodenpasar pada Instagram merupakan salah satu media sosial di Bali yang memiliki implikasi yang sangat besar dalam keamanan dan kelancaran berlalu lintas.

\section{PENUTUP}

\section{Simpulan}

Berdasarkan analisis data yang telah dilakukan dalam penelitian ini, maka dapat dikemukakan beberapa simpulan sebagai berikut:

1. Alasan masyarakat pengguna social media dalam memilih Sosial Media Buzzer @infodenpasar pada Instagram dalam Mencara Informasi Seputar Kota Denpasar. Dalam proses pengambilan keputusan oleh masyarakat, sejumlah proses yang mendasari pengambilan 
keputusan, yaitu: Pencarian Informasi, Mengevaluasi Alternatif, dan Keputusan Pembelian.

2. Strategi Komunikasi Social Media Buzzer @infodenpasar pada Instagram Dalam Menyebarkan Informasi dan Membangun Opini Masyarakat Kota Denpasar. Terdapat beberapa teknik yang dapat digunakan alam strategi komunikasi yaitu antara lain dengan menggunakan Teknik Redudancy, Teknik Canalizing, Teknik Informatif, Teknik Persuasif.

3. Implikasi Social Media Buzzer @infodenpasar Pada Instagram Dalam Menyebarkan Informasi Dan Membangun Opini Masyarakat Kota Denpasar. Seperti halnya Social Media Buzzer@Infodenpasar pada Instagram sebagai suatu pengantar informasi tentu memiliki dampak terhadap masyarakat yang menjadi sasarannya. Adapun implikasi media sosial Buzzer @Infodenpasar terhadap masyarakat Bali dan Denpasar secara mengkhusus adalah sebagai berikut : Implikasi Terhadap Pengembangan Perekonomian Masyarakat, Implikasi Mempermudah Akses Pendidikan, Implikasi dalam Membentuk Etika dan Kesusilaan, Implikasi Keamanan dan Kelancanran Lalu Lintas.

\section{Saran}

Saran merupakan sumbangan pikiran, ide atau gagasan yang bertujuan untuk meminimalisir segala kekurangan yang ada, maka berdasarkan hasil ini penelitian ini dikemukakan beberapa saran sebagai berikut:

1. Bagi akun @infodenpasar pada Instagram agar tetap menjaga eksistensinya sebagai media penyaji informasi dan berita yang independent, netral, dan menjunjung tinggi nilai nilai kebebasan berpendapat, dan menyajikan informasi dan berita sesuai dengan kebutuhan masyarakat khususnya masyarakat kota Denpasar.

2. Bagi pemerintah agar berperan aktif dalam mendukung keberadaan media informasi yang independent berbasis online.

3. Bagi peneliti selanjutnya, diharapakan untuk meneliti aspek aspek yang belum terjangkau dalam penelitian ini.

\section{DAFTAR PUSTAKA}

Adiputra, 2004. Metode Penelitian. Jakarta: Yayasan Gayatri

Effendy, Onong Uchjana. 2004. Dinamika Komunikasi. Bandung: PT. Remaja Rosdakarya.

Fajar, Marhaeni. 2009. IImu Komunikasi Teori dan Prakek. Yogyakarta: Graha IImu

Fandi Tjiptono, 2012. Strategi Pemasaran, ed. 3. Yogyakarta: Andi

Herna. (2019). Strategi Komunikasi Media Sosial Untuk Mendorong Partisipasi Khalayak Pada Situs online Kitabisa.com. Jurnal komunikasi pembangunan, Vol. 17, No.2, Juli 2019. (online).

http://journal.ipb.ac.id/index.php/jurnalkmp /article/view/26843/17217.

Diunduh pada tanggal 21Februari 2020

Hermana, J. Tangahu, B.V. 2003. Metode Analisa. Surabaya: ITS

Iqbal, Hasan. 2002. Pokok-Pokok Metodologi dan Aplikasi. Jakarta : Ghalia Indonesia

Koentjaraningrat, 2007. Manusia Dan Kebudayaan Di Indonesia. Jakarta : Djambatan. 
Koentjaraningrat, 2011. Pengantar Antropologi I. Jakarta: Rineka Cipta.

Kotler, Philip dan Amstrong, Gary, 2014. Principles of Marketing. 15 Th Edition, Pearson Education Limited

LittleJohn, Stephen W dan Foss, Karen A. 2009. Teori Komunikasi: Theories of Human Communication -Buku edisi 9 Terjemahan Indonesia. Jakarta: Salemba Humanika.

Margono. 1996. Metodelogi Penelitian Sosial, Psikologi dan Pendidikan. Jakarta : Gramedia.

Moleong, Lexy. J. 2010. Metode Penelitian Kualitatif. Bandung: PT. Remaja Rosdakarya

Mudyanta Yufiana D. 2018. Strategi Komunikasi Jasa Iklan Instagram @solofoodgram dalam Menghadapi Kompetitor. Universitas Muhammadyah Surakarta(2018).(online)http://eprints .ums.ac.id/66577/1/mudyanta\%20yufi ana\%20L100110100\%20revisi\%20setel ah\%20sidang2.pdf. Diunduh pada tanggal 13 Januari 2020.

Mulyana, Deddy. 2001. Metodelogi Penelitian Kualitatif: Paradigma Baru IImu Komunikasi dan IImu Sosial Lainnya. Bandung. Remaja Rosdakarya. Nawawi. 2005. Metode Penelitian Bidang Sosial. Jakarta: Gunung Agung.

Ni Luh Kade Diah Pradnya Y. 2017. Strategi Komunikasi melalui Media Sosial Dalam Pembenrukan Citra Balebengong sebagai Media Jurnalisme Warga.

Universitas Udayana (2017). (online).

https://www.unud.ac.id/in/tugasakhir11214 05015.html. Diunduh pada tanggal 18 Januari 2020.
Permassanty D, Tanty, Muntiani. 2018. Strategi Komunikasi Komunitas Virtual dalam mempromosikan Tangerang Melalui Media Sosial. Jurnal Penelitian Komunikasi Vol.21. No.2, Desember 2018. (online)

https://bppkibandung.id/index.php/jpk/artic le/view/523. Diunduh pada tanggal 20 Januari 2020

Priansa Juni, 2016. Perilaku Konsumen Dalam Persaingan Bisnis Kontemporer. Bandung: Alfabeta

Prasetya, Irawan. 2004. Logika dan Prosedur Penelitian. Jakarta : STIA LAN PRESS

Rivai, Mulyadi. 2011. Kepemimpinan Dan Perilaku Organisasi. Jakarta : Rajawali Pers.

Schiffman, Leon dan Kanuk, Leslie L. 2014. Perilaku Konsumen. Jakarta: Indeks

Sonny Keraf, 2002. Etika Lingkungan. Jakarta: Penerbit Buku Kompas

Suhardana, 2006. Pengantar Etika dan Moralitas Hindu. Denpasar: Paramita

Sugiono. 2011. Metode Penelitian Kuantitaif, Kualitatif Dan R\&D. Bandung. Alfabeta.

Suksmarini T, Anyes. Strategi Komunikasi MRF Media melalui Instagram dalam mempertahankan Citra Positif $\mathrm{M}$. Ridho Ficardo Sebagai Calon Gubernur Lampung Periode 2019-2024. Universitas lampung (2019). (online).http://digilib.unila.ac.id/5608 0/3/3.\%20SKRIPSI\%2OFULL\%20TA NPA\%20BAB\%20PEMBAHASAN.pdfh di unduh pada tanggal 25 Januari 2020. Supadiayanto. 2020. Pengantar Jurnalisme Konvergentif. Yogyakarta: Pustaka

Baru Press

Suprayoga, Imam. 2003. Metodelogi Penelitian Sosial-Agama. Bandung: Remaja

Roesdakarya. 
Suryadi Edi, 2018. Strategi Komunikasi Sebuah Analisis Teori dan Praktis Di Era Global. Bandung: PT Remaja Rosdakarya

Suryanto. 2015. Pengantar Ilmu Komunikasi. Bandung: CV Pustaka Setia

Susan, Novri. 2009. Pengantar Sosiologi Konflik dan Isu-isu Konflik Kontemporer.

Jakarta. Kencana Prenadamedia Group.

Wirawan, 2015. Teori-Teori Sosial dalam tiga Paradigma. Jakarta. Prenadamedia Goup.

Yudha M Saputra \& Rudyanto, 2005. Pembelajaran Kooperatif Untuk

Meningkatkan Keterampilan Anak Tk. Jakarta: DepDiknas, Dikti, Direktorakt P2TK2PT 